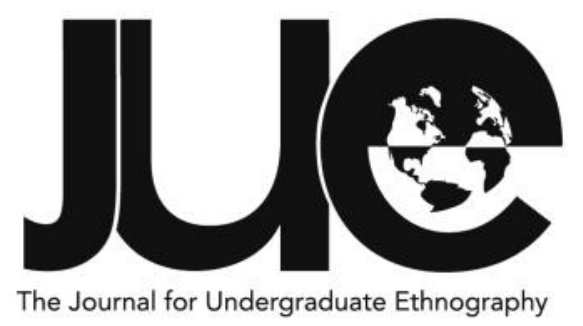
\title{
Nostalgia through Special Rates Areas and Community Improvement Districts in Cape Town Suburbs
}

Being Special:

\author{
Zarreen Kamalie \\ University of Cape Town, kamalie.zarreen@gmail.com
}

\section{ABSTRACT}

This paper explores how memories and nostalgia inform the rationale of implementing Community Improvement Districts (CIDs) or Special Rates Areas (SRAs) as a means of crime prevention and urban maintenance in two formerly 'whites-only' Cape Town suburbs; Rondebosch and Mowbray. Through an exploration of the remembering, the maintenance and the resuscitation of an idealized past in a suburb that remains predominantly white after years of racial and economic exclusion, this paper interrogates the role of long-term resident nostalgia in post-apartheid South Africa in maintaining spatial apartheid. Using Svetlana Boym's (2001) framework of nostalgia, particularly 'restorative nostalgia' and 'reflective nostalgia,' to interpret the memories of residents interviewed, this paper argues that it is nostalgia for an idealized past and a remembered specialness that sustains mentalities that give rise to spatially exclusive SRAs and CIDs. In this paper, public and social media discourse analysis and resident interviews allow us to understand residents' memories and discussions around crime and urban degeneration and homelessness in Rondebosch. The purpose of this paper is to contribute to questions about spatial exclusivity in residential spaces in the post-apartheid era, particularly in a city that retains the legacy of spatial apartheid. 
T he "new" South Africa, born in 1994 from a violent history of apartheid, ${ }^{1}$ has become known worldwide as a success story, largely thanks to Nelson Mandela's legacy. Indeed, it is often called "the rainbow nation," a term coined by Archbishop Desmond Tutu to describe the social landscape of South Africa as a multiracial and multiethnic society living together in harmony as one nation (Spinks 2001, 32). The city of Cape Town, more specifically, is often heralded as a melting pot of racial and ethnic groups. However, Cape Town and the rest of South Africa has an entrenched history of colonial and apartheid laws that dictated access to housing, school, and public space according to race, income, or gender. Some of the better-known laws, including the Group Areas Act of 1950, the Natives Land Act of 1913 and, the lesser-known Vagrancy Act of 1834, are direct causes of what is known as "spatial apartheid", allocating and forcibly moving people of the same racial group in specific areas around the country. To this day it has been challenging to have true integration because the majority of the country's population remains in these areas despite the removal of these laws (Spinks 2001, 8). Two decades after the official end of apartheid, Cape Town remains unintegrated in terms of residential areas and schools. The city still reeks of spatial apartheid and especially in its suburbs, as is seen in the map based on the 2011 census (see figure 1). In the map, we see that a stark majority remains of each racial group in specific areas that were historically assigned to said racial group. The field site of this research project, the suburb of Rondebosch and its neighboring suburb Mowbray, remain predominantly occupied by white people.

As a result of European colonialism and later apartheid, space in South Africa has always been a site of sociopolitical contestation (Ross
2010). Space and specialness are intertwined in this project: habitus is inscribed in the Rondebosch residential area, constructing both "the sense of 'place' and the sense of one's 'place' in a social hierarchy" for white South Africans who have benefitted from colonialism and apartheid in South Africa (Bourdieu 1984, 468; Dovey 2002, 268). In post-apartheid South Africa, race, class, and access to economic capital still largely inform one's habitus, which in turn affects one's degree of access to certain spaces (Bourdieu 1984). This is where 'specialness' comes in. I take the idea of 'specialness' from the establishment of 'Special' Rates Areas (SRAs). A Special Rates Area (SRA) is "a defined area where the majority of property owners decide upon and agree to fund supplementary and complementary services in addition to those normally provided by the City" (City of Cape Town, 2015). According to the Special Ratings Area by-law of 2012, "any owner located within the area of jurisdiction of the City [of Cape Town] and who owns property within the proposed special rating area, may lodge an application to the Council for the determination of a special rating area". This means that an SRA needs to be initiated by a community or any property owner in the area, rather than the City (City of Cape Town 2012, 4). My use of 'specialness', therefore, plays with the idea that people (namely white South Africans that are financially secure, raised in the apartheid era) are used to a particular kind of treatment and service from an organized body similar to the state's service delivery system, because they consider themselves 'special'.

Nostalgia and memory are important aspects in the maintenance of exclusive residential spaces like the predominantly white suburb. Nostalgia and heritage are cornerstones for the Special Rates Areas (SRA) and Community Improvement Districts (CIDS) operating in Rondebosch and Little Mowbray, as well as maintenance and preservation forming a significant part of their agenda. These CIDs seek to restore and maintain a particular 'charm' or 'character' that is found in the nostalgic rhetoric of longtime residents in Rondebosch and Little Mowbray. As I will show, residents mobilize memory and nostalgia as a response mechanism to dealing with perceptions of danger and urban degeneration. 


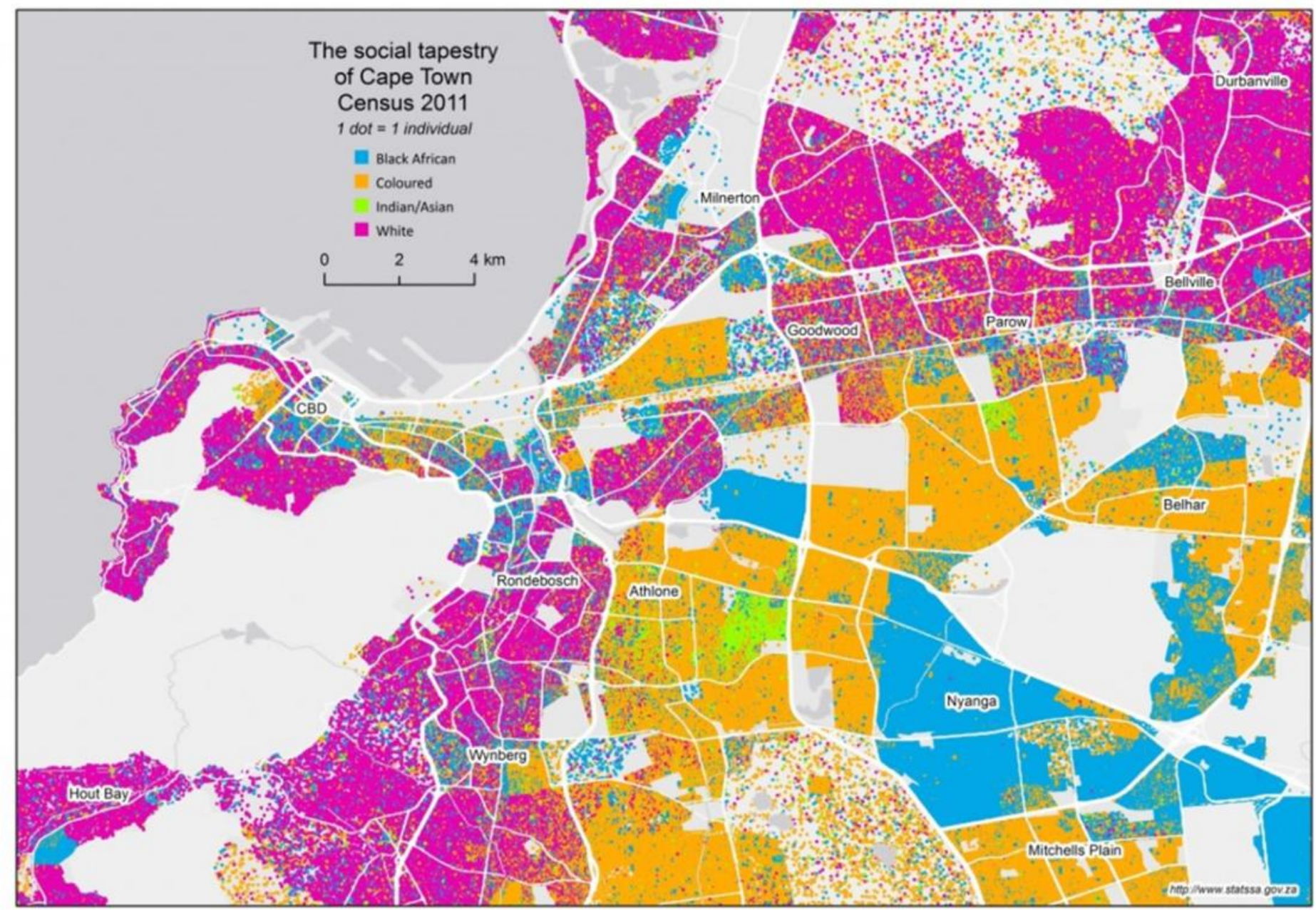

Figure 1 Theil's index of inequality used to depict the social landscape of Cape Town according to race. This is an appropriate visual representation of how spatial apartheid has hindered social integration in Cape Town.

In this paper, I engage with CIDs and SRAs, and their principles and practices when operating in predominantly white suburbs that were residential areas for 'whites-only' under the Apartheid Group Areas Act of 1950. CIDs and SRAs have gained notoriety for supposedly advocating for urban regeneration and market stimulation for the benefit of their fee-paying residents, while simultaneously polarizing neighborhoods and perpetuating the legacy of uneven service delivery across residential spaces, especially in the city of Cape Town (Miraftab 2007, 20). The Groote Schuur Community Improvement District (GSCID), which has been operating in the Rondebosch, Mowbray and Newlands area since 2010, and the Little Mowbray and Rosebank Improvement District (LMRID), which has been in operation since July of 2016, were established on the basis of eradicating "crime" and "grime" in the form of increased surveillance, property and area maintenance, and dealing with the homeless.
"Grime" is used in this context by the GSCID and LMRID to talk about garbage on the streets, unkempt streets or public facilities, and informal settlements by the homeless in the area. While SRAs and CIDs play into the discourse around security, crime prevention, and urban regeneration, their operation in these spaces is also reliant on the financial capabilities of the property owners who are expected to pay a monthly levy in exchange for maintenance and beautification services. These institutions function as long as residents are able and willing to pay. This says a great deal about the relationship between economic standing and the access to land for residence and public use, especially in the context of a city still affected by spatial apartheid.

Drawing on accounts from five women from two suburbs, Rondebosch and Mowbray, I engage with themes of memory and nostalgia through Svetlana Boym's framework of 'reflective nostalgia' and 'restorative 
nostalgia' (2001). I argue that it is through the nostalgia and memories of their childhoods in segregated suburbs that enabled a comfortable life, which sustain and encourage the establishments of CIDs and SRAs in formerly white suburbs. There is a sense of loss and disappointment that comes forth as 'restorative nostalgia' (Boym 2001) in the purpose of SRAs and CIDs. It is a longing to restore the prioritization of white needs in the form of a public space that they can claim first. Certain residents of Rondebosch and Little Mowbray are willing to financially contribute towards SRAs and CIDS because it aligns with their needs and desires as residents in the suburb.

While theft, house burglaries, and incidents of drug use occur in Rondebosch and Little Mowbray, the crime rate in these suburbs is much lower than in lower-income areas, especially with a significantly lower rate of more violent crimes like murder and rape (Crime Stats SA 2015). Yet, residents of these suburbs remember growing up with little to no anxiety about crime, so I argue that there exists a nostalgia that grapples with the desire to maintain standards that were set in an era of exclusion. The purpose of this paper, then, is to interrogate what it means to create inclusive living spaces while wishing to keep the privileges afforded to wealthy residents alone. If we have residents that remember a suburb that was safe and inviting without the presence of people of color, what standard is being reset in a time when spatial apartheid is finding new forms to replicate and sustain itself? Are CIDs and SRAs what Rondebosch and Mowbray need, and how do residents justify this establishment? What factors and considerations are being put forth when residents agree to the operations of CIDs and SRAs? These are the questions that are to be answered in this paper.

\section{Methodology: Rethinking "traditional" research methods}

\section{Online ethnography and the question of access}

I approached this project with a sense of perceived familiarity, thinking that since the discourse of the fearful suburban white was so rampant on social media, I would be able to recite my participant's fears back to them, or that because I knew what it meant to drive by these homes with high walls that I would know the person nestled securely behind them. At the same, I gauged the topic with caution, because I came to the realization that the research participants could not be homogenized, in spite of the prominence of a singular narrative on social media. There are many aspects of this encounter with the walled house from which one could extrapolate arguments around spatial exclusivity, residential discrimination, and racially charged security discourses. However, I wish to consider the nuances of studying experiences and understandings of security in the context of social media, Community Improvement Districts (CIDs), and Special Rates Areas (SRAs). This will become important later, when I discuss the maintenance and reproduction of the historicized legacy of spatialised value in this city.

I had intentionally chosen to do my fieldwork in Rondebosch, my place of residence for the last four years, because I wanted to challenge myself, as an anthropologist, to seek the substance behind the mantra they taught us in first year; make the familiar strange. Heike Becker, Emile Boonzaier and Joy Owen (2005), along with Angela P. Cheater (1987) touch on citizen anthropology and the concept of 'anthropology at home'. Anthropologists who do ethnography in their own society are said to transcend the paradigmatic dichotomy of "regular/outsider" and "native/insider" anthropology that is largely determined by reproduced ideas of "bounded cultures" (Cheater 1987, 124). However, I was only acquainted with the Rondebosch suburbs in as far as I would pass them when running or see them from a car. Not knowing anyone who lived in the walled houses of the Rondebosch and Mowbray suburbs, I resorted to Facebook.

If the goal and role of anthropologists is to gain trust in their field site and among their participants, I had to find a way to familiarize myself with the suburbs of Rondebosch before actually going there. I realized that the suburbs were not a friendly space for outsiders; or rather, for outsiders who are not looking for work, and even then, their presence is met with suspicion. Instead, I took to social media. I 
joined a Facebook group called 'Rondebosch Community' in June, a few months before starting my fieldwork as a means to get to know how residents in the Rondebosch community felt towards issues around their safety and security. These Facebook groups are typically managed by one or more person(s) who have the authority to regulate content, allow or remove members, and even shut down the group. Online ethnography (Rheingold 1993; see also, Gatson 2010, 247) can be characterized as having the same tenets of 'traditional' forms of ethnography but with an extended reach, creating a "more permeable and less physically bounded" site (Gatson 2010, 247). Howard Rheingold's The Virtual Community (1993) explored the multiple and connected online and offline places and spaces in which his community existed (Gatson 2010, 248). With this method I was able to access a kind of membership that I could not attain by virtue of not being a homeowner or long-term resident as my research participants are. This group also allowed me to explain myself and recruit informants for interviews.

Interviews: A conversation with a purpose Interviews serve as a primary source of research and qualitative data that are, to an extent, independent from the researcher's own biases and subjectivity. James Scheurich (1997, 61) quotes Lincoln and Guba (1985, 268), who explain interviewing as a "conversation with a purpose." The purpose of the oral history interviews I conducted was to give background to the comments and complaints on the Facebook groups I was observing. I wanted to know what led to the perceived need for a CID or an SRA, and interviews provided participants with an "opportunity to tell [their] own story in [their] own terms" (Anderson and Jack 1991, 11). In terms of ethical considerations, I made sure to only meet in sites where interviewees felt comfortable. Although I told them that I would prefer to see their homes, given my initial research topic, I always left the option open to meet in a more public place first. Before beginning the interview, I made sure to ask for verbal consent and told them that they had the option of retracting their consent if ever they were unhappy with what was being produced. The participants in this study are all women, since an overwhelming majority of the respondents were women. I also made sure to let the women know when and if I was beginning to veer away from the initial topic of material responses to the threat of crime, for instance fences, walls, barbed wiring and alarm systems. I realized early on that many residents with these security measures might meet my project with suspicion considering the awareness around scams and crime syndicates in the area.

The questions would start off with an introductory set up, usually 'how long have you lived in this house? And did it always have the wall/fence outside?' 'Have you ever had any break ins? How have your security systems made you feel safer since installing them?' The answers would vary, with some of their answers surprising even those interviewed. "I'm really quite strange in that way" or "I think we might be unique that way," they would interject when they disclosed the way they regularly left a door open without thinking, or kept a dysfunctional alarm for years without worry. Their engagements with their security systems went against the dominant narrative of neuroticism and paranoia. Eventually, however, our conversations would make their way to their memories of living in the Rondebosch suburb during apartheid. Through these narratives, I found the complexity and nuance of responses to crime and security threats.

\section{Theoretical background: Theorizing specialness and suburban nostalgia}

Themes in this paper span from social distinction to spatial exclusivity and more specifically, how these are justified through nostalgia, memory and continuity, and how they manifest in discourse and practice around security in formerly privileged areas. The themes of memory and nostalgia are critical to explain how and why specialness is maintained, and what this means for the research question regarding continuity as a response to crime and urban degeneration in once glorified exclusive spaces.

Charlotte Lemanski has written about residential responses to fear and how they factor into the implementation of Improvement 
districts and gated communities (2006, 787); Lemanski carried out her research in Silvertree and Muizenburg, two historically white residential suburbs in the southern suburbs area of Cape Town, (2006, 789). Lemanski concludes that it may require several postapartheid generations to challenge the "fears and mindsets 'embedded' in people's "institutional and social practices" (2006, 787). This is essentially where my research picks up, ten years later, to suggest that these 'embedded institutional and social practices' are the desire and nostalgia for specialness.

Under the laws of apartheid, certain social groups were classified as being more 'special' than the rest. This classification would go on to shape an entrenching legacy, creating a small but "dominant class", as Bourdieu would say $(1984,260)$. Rondebosch, as a place formerly determined as 'whites only' and therefore 'special,' can be described as a "relatively autonomous space whose structure is defined by the distribution of economic and cultural capital among its members" (Bourdieu 1984, 260). This essentially means that by nature of benefitting from a legacy of structural privilege, residents, particularly the wealthiest of them, are able to exact a kind of agency separate from the city council in order to retain its economic and cultural capital, to maintain its 'specialness' amongst their own. As a result of being used to this treatment, the white middle class seeks to regain a space of distinction. Distinction, in this case, is determined by those who are familiar with the rules of value and prestige and can identify something, be it art, music or architecture, as being aesthetically valuable (Bourdieu 1984, 53-56). Rondebosch, with its European colonial landmarks, wellmaintained and policed suburbs and other surroundings, is deemed 'prime property' and holds socioeconomic value.

The social product of a shared social space, in this context, is the shared nostalgia that residents of Rondebosch grapple with in the post-apartheid era. Stephen Legg references Boym's (2001) definition of nostalgia in the context of space and home as "the longing for a home that no longer exists - or never existed" (Legg 2004, 100). For Boym (2001), restorative nostalgia "ends up reconstructing emblems and rituals of home and homeland in an attempt to conquer and spatialize time" while reflective nostalgia "cherishes shattered fragments of memory and temporalizes space" (49). Boym (2001) defines nostalgia as "a romance of one's fantasy" (xiv). The word 'fantasy' alludes to the imaginary component of that which is being longed for. In this case, the 'fantasy' is the reproduction of the past in spite of the present. SRAs and CIDs like GSCID and LMRID recycle nostalgia to establish practices that seek to restore Rondebosch, its surrounding areas, and areas that share a similar history to it, to a state that resembles colonial and/or apartheid Rondebosch. While Boym's work centers on post-Communist Eastern Europe, I apply her paradigm to the post-colonial and post-apartheid setting of Rondebosch to think through these ideas of the romanticized colonial era. Not only has her work been cited by other South African scholars to work through similar questions, but her paradigm fits the ways that white South Africans speak about the apartheid past, due to their benefitting from the system.

Overall, the aforementioned works will feature prominently in this thesis to put forth the argument that SRAs and CIDs mobilize and manipulate public desire for continuity in their residential areas, as means of addressing resident security concerns. Throughout this paper, I argue that GSCID, and the up and coming LMRID, have an agenda based on the maintenance of exclusive suburbs by upholding a standard deemed to have economic value. Rondebosch and Little Mowbray are prime real estate areas due to the capital brought in by white South Africans who benefited from apartheid. It is a continued desire for these suburbs' residents for this status quo to be maintained, and as a result the actions of GSCID and LMRID is justified by nostalgia and a desire for a continuity of specialness.

\section{The making and remembering of specialness: Reflective nostalgia and collective memory among} research participants

From maintaining the facades of Victorian-era homes to putting up walls to replicate a sense of safety, these elements make visible the white 
middle-class habitus of Rondebosch and the practices of residents who have inscribed a sense of belonging onto the landscape. I engage with how residents reflect upon this, and how this narrative makes its way into discussions around crime and security, and practices of GSCID and LMRID. The five women I interviewed are all long-term residents of Rondebosch or Little Mowbray, each having stayed in the suburb for at least eight years either after moving or having grown up there. The first two that I introduce together are Sheri and Alice, who both came from the United Kingdom originally and relocated to South Africa during the apartheid years. They exercise reflective nostalgia in the ways that they describe their experiences of apartheid in terms of a perceived sense of security and ease of living. Next are locals Simone, Janet, and Lillian. Simone and Janet had grown up in Rondebosch, though Janet moved to Little Mowbray when she got older. Lillian is originally from a northern province in the country and moved down to Cape Town many years ago. The following sections are parts of their stories, and show the variety of ways that nostalgia and memory resurface and shape their needs and desires of living space.

\section{Britons overseas: Sheri and Alice}

By 1990, there were 223,205 'Brits' living in South Africa (Flanagan, 2014). I met with two British women who have lived in South Africa for at least two decades; one lived in the Western Cape since the early nineties but had a history of visiting regularly, and the other had lived all over South Africa since she married a South African man. Both of the British women reside in Victorian homes, and have a clear fondness for living in Cape Town. Reflective nostalgia takes on a different form for these women because they are foreigners, and as a result, have not taken on the same feelings of reflection as participants that are South African. As white British women, however, they too enjoy a degree of privilege, and have the same access to privilege that other white South Africans do, on account of colonial and apartheid legacies.

Alice is the only participant who lives outside the Rosebank/Rondebosch, Mowbray area but was part of the Rondebosch Community
Facebook group. Despite living outside of the designated field site, I was intrigued by how intent she was to draw attention to the crime in her own suburb, despite my call to residents in Rondebosch and Mowbray alone. She lives in an old Victorian home, with a low fence and a small front garden. The façade remains, while the inside has deteriorated with damp, dry rot, only to take on a new character through the vivid blue and orange interior of her kitchen. She lamented the dry rot and the dilapidated nature of the home, but excused them as 'charms' and 'quirks' of living in a Victorian home. Her neighborhood is scattered with many such homes, a clear and defining feature that draws residents. Alice has lived in South Africa for many years, having moved around the country and finally settling in Newlands, a small but beautiful suburb famous for its international rugby stadium. Alice responds to her perception of crime rates in South Africa during her time in the country with a sense of absolution; shifting blame to the apartheid government alone, she links the rate of crime to the education crisis that plagues South Africa's poorer populations.

When I came here, it was apartheid still and I didn't think about...I didn't think beyond the family circle. And we didn't have the crime we have nowadays...and...that's partly the fault of the apartheid government in that they didn't educate the people. For me education! If we can educate people they will get better jobs, they will learn not to...have so many children. Population reduction! That's what we need!

Alice employs what Melissa Steyn calls "white talk" $(2005,120)$. This can be understood as "a set of discursive practices that attempts to manage the intersectional positionality of white South Africans to their greatest advantage, given the changes in their position within the society" (Steyn, 2005, 120). White talk also features frequently in the narrative of the CIDs operating in Rondebosch and Little Mowbray, especially in the ways that homelessness is addressed, which is explored further in this paper. 
Sheri had been one of the last few to reach out. Her home is a large salmon-colored Victorian house: two stories with big long windows that do not have burglar bars. As we sat down, Sheri began to ask and make sure that I am indeed a student from UCT. Sheri explained that her husband had had his doubts, but that she personally could not see what harm I could do "I said, it's not like I'm going to give her the security codes!" she said, recounting an earlier conversation with her husband. But she had to be sure nonetheless. Sheri had been coming to Rondebosch for years on account of her grandparents. She and her family would visit when she was young, and then she started coming through to South Africa on her own as a teenager. When asked about her experiences and memories of Rondebosch, Sheri described the area as "completely safe."

\section{Walls and fences: Simone, Janet, and Lillian}

Simone and Janet both grew up in Rondebosch, and have spent most of their life either in the area or in surrounding Mowbray. Simone has lived in her home on Campground Road for eight years, having moved to the suburb after a traumatic home invasion in Hout Bay. Simone grew up in Rosebank during the sixties through to the eighties. She went to Rustenburg Junior School, and lived with her grandmother whose house is now currently the Rosebank Progress College. Janet, a crèche schoolteacher, is settled in Little Mowbray. Janet remembers a sense of freedom and a lack of anxiety regarding their safety and well-being. Lastly, I met Lillian, who has lived in Rosebank since 1982. She had been very involved in the neighborhood watch, and security is very important to her. Her view of security however, is not limited to simply high walls and fences - Lillian is invested in the revitalization of public space and dealing with 'vagrancy' with a "hands on" approach. She is also vehemently against the implementation of the GSCID.

I feel [angry about] the SRA, where four people are now in control of my suburb. We don't need an SRA for our area; it's not an area that is downtrodden and needs upgrading. I'm beginning to feel that rage that people under apartheid must have felt, that powerlessness that you've now landed with this system. That's now imposed on you.

There is an unmistakable irony in comparing SRAs to apartheid policy, given that SRAs principally seek to reform previously advantaged areas under apartheid to some sense of former glory. Lillian's comment, I would argue, shows the kind of complexity in compliancy and contestation, when one both opposes the institution but manages to uphold its principles because of a genuine disengagement with the history of the area. By sharing a particular habitus and having benefitted from the apartheid-era suburb, they are able to reproduce 'specialness' through collective memory that constitutes the "shared social frameworks of individual recollections" (Boym 2001, 53). With Alice's comment about her ambivalence towards apartheid and Lillian's offhand comparison between the GSCID and apartheid, we see how their habitus enables a disassociated look back at the conditions that apartheid created. Without having experienced the oppression of the regime themselves, they can only imagine the circumstances in the past and recreate a scenario that is best suited to their narrative.

In the following sections, I draw on the interviews with these five women to explore themes around a perceived loss of a charming childhood setting, in spite of its place in a violent segregationist regime. I include a published article on a British colonial era horse trough named 'the fountain', and its nostalgic presence in Rondebosch, and examine the discourse of the GSCID when it had to be removed (Van Dyk 2016). In addition to the nostalgic rhetoric, there is also a degree of 'white talk' in the article. Secondly, I look at themes around collective memory in a community's past and its continuity, while also looking at the narrative of homelessness in the GSCID's agenda and residents' interviews. Taking part of the conversations with the women, along with public statements issued through the news or GSCID's own website, the rest of this paper weaves a tapestry of the different forms that nostalgia takes in the setting of this suburb. 
Loss of charm and character:

Reflective vs. restorative

\section{nostalgia in specialness}

Since the fall of apartheid, there have been many studies on the loss of political and social power by South African whites. More recently, however, authors like Melissa Steyn (2008; 2012) and Sarah Nuttall (2001) have chronicled various ways that white South Africans have navigated this new socio-political landscape. I contribute to this literature by arguing that one way this occurs is through the implementation of SRAs and CIDs for public and residential spaces in previously advantaged and presently privileged spaces. These institutions are, principally, a nostalgic response to a continually changing landscape.

The GSCID acknowledges and builds upon this sense of belonging through a narrative that suggests a "loss" is currently being experienced by white residents of Rondebosch. It is the loss of heritage, space and power that prompts residents to lament a history that romanticizes their sense of belonging and ownership. This was echoed in public media in 2016, when News24 released an online article titled, 'Character Disappearing,' whereby a resident mourned, "the disappearance of the charming character this area was once so well known for" (Van Dyk 2016). The article recorded a recent discussion between a concerned resident from the Rondebosch area and Anthony Davies, the CEO of the GSCID. The topic of the article was the "ongoing deterioration of the Rondebosch Village", the beginnings of which were with the disappearance of 'the fountain' on the corner of Belmont and Main Road (Van Dyk 2016). 'The fountain' was one of the better known landmarks in the area, before its removal following a motor accident that saw a reckless driver crash into the structure (Jeranji 2015). Although referred to as 'the fountain', it was actually an ornamental trough for watering horses (Bull 2016, 57). Manufactured in England, and brought to South Africa in 1891, 'the fountain' was also the first electric lamp post in South Africa (Geldenhuys 2014, 267). As an ornamental monument marking the British colonial presence in Rondebosch, 'the fountain' was one of the subtler markers of this legacy.
When a roadside accident led to the destruction and removal of 'the fountain', GSCID CEO Anthony Davies issued a statement on how it had great sentimental and historical value, and that its destruction caused the residents of the area great disappointment; he went on to say, "It [kept] us humble because when we look at it we see how far we have come from. Everybody liked it. Horses used to drink there before the cars came so it's so special." Taking into account the history of Rondebosch and Mowbray during the colonial era and the apartheid era, it is important to consider how residents respond to what they deem to be degeneration and 'loss of charm and character'. They appear to subscribe to the idea that in order for security to be instilled and maintained, the 'safest' option is to revert to or resuscitate the glorified past. This understanding of prestige and value grows out of the romanticism of colonialism, which was effectively a period of conquest, subsequent forced removals and sociodemographic rearrangements in the name of 'separate development', a social development plan laid down by Henrik Verwoerd. It established racially bounded spaces created with the direct intention of prioritising the development needs of one racial group over others (Beck, 2014, 136). Today, when residential spaces can no longer be 'separate', they can instead be 'special'.

Sheri's accounts from her early life are interesting in that her decision to move to South Africa was partly shaped by positive experiences that were made possible through coercive and covert systems that were put in place on the basis of the dream colonial topography. Sheri grew up in London, England, but regularly visited South Africa on account of her South African grandparents who resided in Rondebosch.

It never crossed my mind that it wasn't safe...sometimes I'd visit my grandparents without my parents. I was a teenager, and I would walk to a pub with friends when I was a teenager. At night. I mean, I would do that in London, and I wouldn't think it'd be any different here.

For Sheri, Rondebosch is characterized as a space of familiarity - even in the way in which 
she reminisced about how, as a teenager visiting her grandparents, she would walk to the local pub in Rondebosch "because that's what [she] would do in London, and [she] wouldn't think that it'd be any different here". The likeness that she draws between Rondebosch and London, in terms of freedom of movement, ignores the fact that the former is only made to be like the latter through the exclusion of the majority of its population. It means the reproduction of place in a foreign space by pushing out those who were the original inhabitants and recreating the colony through architecture and monuments that reference the colonial power.

Alice moved to South Africa when she married a South African; she has been here for about forty-three years but has lived in Cape Town for eighteen of those years. Having lived in Johannesburg, in a small holding with about half an acre of property with paling fences that were really high (courtesy of her husband), she remarked that "I'd never really felt insecure there" nor had she when she lived at a game farm "in the bush", as Alice put it. Alice often employs 'white talk' when speaking about crime in her neighborhood. Her 'white talk' can be considered a form of reflective nostalgia in the way that white people in South Africa reflect on, complain about, and lament over what once was, until they create new narratives through which to voice their concerns.

Alice's concerns with crime are not unfounded considering the mugging she had experienced a year before. She told me how it affected the way she moved around in her neighborhood afterwards: "[For] ages afterwards I had a kind of paranoia about walking in the street. I had used to walk to Riverside almost every day, but I stopped that. I won't walk that route anymore...but we're still not as bad as Johannesburg [laughs], or at least I tell myself that." It is a common phrase among white Capetonians - "not as bad as Johannesburg"; it says that no matter how bad crime gets in Cape Town, it is still 'better than Johannesburg'. This rhetoric is part of what Steyn calls, 'white talk'. Alice's 'white talk', even as a non-South African, also comes through when she deems the solution to crime to be education and "population reduction", echoing a common discourse around the reason behind crime in South Africa among the white middle class. Alice's 'white talk' becomes part of her reflective nostalgia as well since the place she lived was not crime ridden and dangerous. In her case, she is able to recall a time when she felt safe much of the time.

While Alice approached the topic of security with 'white talk', Simone told me of how she fortified her home following an attack on her and her husband in Hout Bay. When Simone and her husband, lan, moved to Rondebosch the first thing they did was raise the walls of their home. Simone said:

When we moved in, I was very afraid because the house is one story and we were attacked when in a double story. Previously, there has been a door/gate in the wall in the backyard that led to the common and we closed that and put electric fencing there too. We replaced the gates...we elevated the walls and electric fencing and this really upset the neighbors, especially this neighbor here [motions to her front wall]. She wrote me a letter, saying, 'how can you make this place look like Alcatraz! This is a gentle little suburb in Rosebank and we don't have housebreaks and this is a culde-sac'. I kinda felt a bit bad but we needed it. We [she and her husband] both like open spaces and hate burglar bars ...so we use beams...yes we're quite open but we've put in all the state of the art security features.

This was about ten years ago, and in that time, "the gentle little suburb" had now taken on a character of fortification all along the road. That distress that we see from Simone's neighbor years ago shows the role of memory and nostalgia even from individuals outside of my own fieldwork. This neighbor displayed their own form of nostalgia in the way in which they were so taken aback by the changes in their suburb, and through Simone, I witnessed her own reflection on the interaction. 
While not necessarily with the intention of actively creating an exclusionary space, these women perpetuate a narrative that can be mobilized by others to establish an SRA or a CID. By simply reflecting on what once was, without considering the means by which it was possible, there cannot be any moving away from the ineffective ways that white suburbia engages with crime in exclusionary forms. While there was some acknowledgement of the past, there is very little to no engagement with my participants' own complicity in the making and perpetuating of a racially and economically exclusive structure. Instead, the response has been to retain the mechanisms that reinforce their specialness. We see the convergence of deeply embedded appreciation of European architecture and the collective memories of the white middle class who have both gained and lost - and how they are trying to maintain some sense of what they had without really seeming to know how to do so.

\section{(Dis)continuity of community: 'Grime' management and recollections of the homeless}

The GSCID and LMRID's 'crime and grime' narrative, and its agenda to get rid of the two, is based on the idea that an unkempt public space, be it a rundown park or broken pavement, attracts illegal activity because of the implication that it is forgotten and goes unnoticed by the authorities. In turn, with these spaces being less frequented by the public because of criminal activity, criminal activity contributes to the degradation of public spaces. Homelessness and vagrancy, for instance, happens to be one of the issues at the intersection of "crime" and "grime", categorized as "grime." Here, I draw on GSCID's approach and narrative towards homelessness and vagrancy, as well as the responses from the women I interviewed, to discuss the conflation of homeless people with "crime and grime."

When asked about the presence of the homeless, the women had various memories of their place in the suburb previously as well as opinions on how best to navigate around them. Janet, who grew up in Rondebosch and later moved to Mowbray, laments the state and standard of living that enabled her children to roam around freely. She is also quite passionate about the reclamation of public space, and it was through my conversations with her that I began to be able to draw the links between a sense of loss and a sense of wanting to recreate, though not being able to reconcile that nostalgia with the realities of the past.

Author: So I mean, it sounds like people are finding ways in which to reclaim a sense of place that sort of mimics what the might have used to be in the past, and being aware of and taking into account things like homelessness, because I mean, I dunno how many homeless people were around when you were a child...

Janet: Uhhh...no. No...not...many. No. No.

Homelessness and vagrancy are suggested to be part of urban degeneration and dilapidation. This perception informs how people remember their childhoods without the presence of the homeless. The absence of the homeless in their memories also convinces residents like Janet that there was little to no crime in their recollections. As part of the maintenance agenda, GSCID and LMRID approach the homelessness issue with an attitude of getting them out of the public eye, rather than finding a sustainable solution through integrating them into the community. When I left Janet's home, however, she sent me a message saying that she was mistaken in saying that there were no homeless people. The message went as follows:

\section{Hi Zareen}

My memory was not serving me well yesterday. I do remember lots of street people when I was in primary and high school and a student as well. Particularly along R'bosch main $\mathrm{Rd}$. Meth drinkers and a bands of street children who were glue sniffers. They would sit at traffic lights and beg. Lots of unruly behaviour after hours. When I was a student living in Vredehoek there were lots of street people and they were far more intrusive than they are now!

Janet 
Yet she had been quick to denounce the presence of homeless people the day before. While anyone can forget things, especially after many years, it was interesting to consider that the romanticized image of Rodenbosch might be so engrained in Janet's mind that she has begun to recreate it. If the same were true for other residents, it could help explain why they feel crime has increased in the years following 1994. Boym (2001) explains that one of the dangers of nostalgia is that it "tends to confuse the actual home and the imaginary one" (xvi). In this case, we see how Janet had become accustomed to reflecting on the past as a better time that she went as far as forgetting the negative aspects that are currently being promoted as new. News articles that speak of "restoring character" also give the impression that homelessness and vagrancy are new to Rondebosch and as a result are responsible for the degeneration of public space that once was pristine and glorious. Robert Fishman (1987) asserts, "that exclusion is routinely at the very core of utopias" (4). If we were to elaborate on this, then I would say that the character and charm of Rondebosch was fundamentally built upon the exclusion of marginalized peoples such as the homeless. In 2015, GSCID released as article titled Homeless Hinder River Projects (GSCID 2015). The focus of the article was the concern of GSCID's top members over the state of the river as a result of the homeless people, for example: "the biggest issue we encounter is the damage caused by the homeless people living along the river bank. They set up temporary shelters at various spots along the river and use the river itself and the river's edges to do their ablutions" (GSCID, 2015).

Lillian spoke at length about different aspects of safety and security she took into account. One of these aspects was how and why she engaged with people who live on the streets; the homeless, or "vagrants". When I first met Lillian at her home, she had explained to me how she became involved with them:

I got interested in investigating absolutely everything along Main Road. Because I felt that GSCID was doing nothing. All they were doing was moving people out of the way. And self-promoting, but they actually are not doing anything. So through being with these people I learnt that the most important thing they need is water to drink, and we won't provide water fountains because we don't want homeless people in our area. They come to the Liesbeek River and we don't want them there because they're dirty and scruffy, but actually they need to wash their clothes and they want to wash their bodies.

Lillian would like to refurbish the Alma Park, reopen the ablutions block and create a kind of public space that is useful and accessible to 'vagrants'.

Author : I was looking at the park you're wanting to-

Lillian: Oh, transform!

Author : Yeah, and you said something about an ablutions facility

Lillian: Yes, there's a little building at the bottom, that was an ablutions block but it's locked, and the social worker has the key. But we need an ablution block there. And it needs to be maintained by the city because every other day we have soccer games... it would be fabulous place for the homeless to wash their clothes and...I've said l'd be happy to monitor and manage it from, say, 8$10 . .$. There are all these potential little projects.

Author: Do you think that people in your neighborhood could object, and cry 'what if it turns into a squatter camp?'

Lillian: Oh, they see a squatter camp on every corner! (laughs)

When I had mentioned Lillian's idea to Sheri, her response was critical:

Umm... it kinda depends on if it becomes their place to live, and if it does, what's to stop it from becoming a squatter camp or an informal settlement? Because you 
can't have an open space and expect people to live on bench, or something like that. So, and then it becomes not an open space for everybody. I think if you want to do something, then make a shelter. Find someplace that can be used as a shelter...Otherwise, I don't think it'll remain a park...in the same way that the subway didn't remain a subway [starts laughing]...it very quickly became a little shanty town. In the space of about a week [laughs].

Another aspect of understanding restorative nostalgia is to "distinguish between the habits of the past" versus "the habits of the restoration of the past" (Boym 2001, 42). The actions of Rondebosch residents mimic and replicate the spirit of the colonial era in the way that property owning residents feel that they have ownership of public space in their suburb by way of owning a house there. There existed a series of Acts dedicated to the policing of vagrancy during the colonial era, such as the Vagrancy Act of 1834 (Crais 1992, 140). What is left is a suburb that normalizes the exclusion of poor people of color in "their" public spaces. The Vagrancy Act constitutes a "habit of the past', but as was argued, it still finds its principles and practices reproduced to create 'habits of the restoration of the past'. Part of the habit of restoring the past is the idea that there is something to be learnt from it. The fault lies in thinking that it holds all the answers, leaving little room for the unconventional when it comes to ideas of modernity and progress in shared living spaces. For Lillian to transform a public space that is meant for Rondebosch residents, irrespective of whether they actually use it, into a space for a marginalized yet very present population in the area goes against the 'values' that restorative nostalgia would champion. Sheri's response that the park could likely turn into that which resembles a 'shanty town' or 'squatter camp', both of which are infrastructural symbols of poor black populations in South Africa, shows that there does indeed exist a desire to retain a particular image that is separate and devoid of the ills of the past.

\section{Conclusion}

Ultimately, we see that the basis of these community organizations is the upkeep of standards set in place by a racially and economically exclusive legacy. There is little room for fluidity, which can be seen through the conservative understandings present among local residents and CID and SRA officials of what it means to be part of the community. Part of being a long-term resident in these affluent suburbs is being able to engage with the collective memory of being a beneficiary of the apartheid system. The nostalgia of Rondebosch and Mowbray long-term residents is supported by those who collectively identify the change in their suburb as degradation from what was once prestigious. These sentiments are then taken on by SRAs and CIDs like GSCID and LMRID, to become the principles and practices upon which these organizations operate.

There exist similarities in the ways the women I interviewed remembered Rondebosch, especially Simone and Janet, who had grown up in the neighborhood, but each participant had their own angle and interrogated the past in their own way. Instead of generalizing, I have attempted to present these accounts as anecdotal and use these narratives as a lens through which to explore the making and remembering of specialness based on their experiences and memories of apartheid era suburbia. Through this, I was able to understand how and why people reminisce and the degree to which certain narratives are perpetuated by SRAs and CIDs like GSCID and LMRID.

Unlike Lemanski (2006), who approached the topic of SRAs and CIDs from the standpoint of spatiality and urban planning, I attempted to investigate the motivations and rationale behind these institutions. There is still much to be explored around CIDs and SRAs operating in other Cape Town suburbs, especially suburbs going through this transitionary period in postapartheid South Africa. In the meantime, however, this paper can function as a starting point for my own extended research at the intersections of whiteness, spatiality and memory. The purpose of this paper has been to shed light on the unsustainable rationale of 
these organizations. In potential future research, either for myself or someone else, I would like to see SRAs and CIDs engaged with holistically. This paper does not serve to provide solutions for combating crime, but rather to put forth alternative ideas for understanding community and what this means for security. Hence, there remains room and need for exploration into the competing ideas for the future of suburbia in South Africa.

\section{Endnotes}

1. Apartheid was a system of institutionalized racial segregation and discrimination in South Africa that existed between from 1948 to 1994. Apartheid can be characterized by petty apartheid where public facilities such as beaches and toilets, or social events were racially segregated, and grand apartheid, which dictated housing, land allocation, schooling and employment opportunities by race (Beck 2014, 135). 


\section{References}

Beck, Roger. 2014. The History of South Africa, 2nd edn. California: ABC-CLIO, LLC.

Becker, Heike, Emile Boonzaier, and Joy Owen. 2005. "Fieldwork in Shared Spaces: Positionality, Power and Ethics of Citizen Anthropologists in Southern Africa." Anthropology Southern Africa. 28(3\&4): 123 - 132.

Bourdieu, Pierre. 1984. Distinction: A Social Critique of the Judgment of Taste. London: Routledge.

Boym, Svetlana. 2001. The Future of Nostalgia. New York: Basic Books.

Bull, Esme. 2016. "In Memoriam Fontis Ad Orbem Spinarumi, 18912015." Cabo, 2016(1). 57-59.

Crais, Clifton C. 1992. White Supremacy and Black Resistance in Preindustrial South Africa: The Making of the Colonial Order in the Eastern Cape, 1770 - 1865. New York: Cambridge University Press.

Crime Stats SA. 2015. "Provincial Statistics: Western Cape". Accessed October 15. https://www.crimestatssa.com/province.php? ShowProvince $=$ Western+Cape

Dovey, Kim. 2002. "The Silent Complicity of Architecture." In Habitus: Sense of Place, edited by Jean Hillier and Emma Rooksby, 267 - 280. England and USA: Ashgate Publishing Ltd.

Fishman, Robert. 1987. Bourgeois Utopias: The Rise and Fall of Suburbia. New York: Basic Books.

Geldenhuys, Preller. 2015. Geldenhuys Genealogy: Descendants of Albert Barends Gildenhuizen. Everton: Just Done Productions.

GSCID. 2016. "Groot Schuur Community Improvement District". Accessed November 8. 2016. http://www.gscid.co.za.

. 2015. "Appeal to Restore Rondebosch Village Character." Accessed November 16. 2016. http://www.gscid.co.za/appealto-restore-rondebosch-village-character.

Jeranji, Tiyese. 2015. "History Smashed Into Pieces." News24. Last modified 2015. Accessed November 8, 2016. http:// www.news24.com/SouthAfrica/Local/Peoples-Post/Historysmashed-into-pieces-20150824-3.

Lefebvre, Henri. 1991. The Production of Space. Translated by Donald Nicholson-Smith. Oxford: Blackwell. 
Legg, Stephen. 2004. "Memory and Nostalgia." Cultural Geographies. 11(1): 99-107.

Lemanski, Charlotte. 2006. "Residential Responses to Fear (of Crime Plus) in Two Cape Town Suburbs: Implications for the PostApartheid City." Journal of International Development. 18(6): 787-802.

Lincoln, Yvonna S., and Egon G. Guba. 1985. Naturalistic Inquiry. Beverly Hills: SAGE Publications.

LMRID. 2015. "Little Mowbray and Rosebank Community Perception Survey." Accessed November 10, 2016. http://Imrid.capetown/ wp-content/uploads/2015/06/Little-Mowbray-Rosebankcommunity-survey-summary.pdf.

Miraftab, Faranak. 2007. Governing Post Apartheid Spatiality: Implementing City Improvement Districts in Cape Town. Antipode 39(4): 602-626.

. 2012. "Colonial Present: Legacies of the Past in Contemporary Urban Practices in Cape Town, South Africa." Journal of Planning History 11(4): 283-307.

Rheingold, Howard. 1993. The Virtual Community. Cambridge: MIT Press

Scheurich, James Joseph. 1997. Research Method in the Postmodern. London: Falmer Press.

Spinks, Charlotte. 2001. "A New Apartheid? Urban Spatiality, (fear of) Crime, and Segregation in Cape Town, South Africa." Destin: Working Paper Series. 01-20. 3-33.

Steyn, Melissa. 2001. "Whiteness Just Isn't What It Used To Be": White Identity in a Changing South Africa. New York: State University of New York Press Albany.

. 2005. "White Talk": White South Africans and the Management of Diaspora Whiteness. In Postcolonial Whiteness: A Critical Reader on Race and Empire, edited by Alfred J. Lopez, 103-119. New York: State University of New York Press.

Steyn, Melissa, and Dan Foster. 2008. "Repertoires for Talking White: Resistant Whiteness in Post-Apartheid South Africa." Ethnic and Racial Studies, 31(1):25-51.

Van Dyk, Gary. 2016. "Character Disappearing" News24. Accessed November 8, 2016. http://www.news24.com/SouthAfrica/ Local/Peoples-Post/character-disappearing-20160829. 